\title{
ICT DALAM PEMBELAJARAN BAHASA ARAB
}

\author{
Fatwa Arifah \\ Universitas Negeri Jakarta \\ Email: anafatwa@yahoo.com
}

\begin{abstract}
ICT in education becomes a matter being discussed at this time. Arabic Language Learning as a part of a Foreign Language Learning is one of many aspect that influenced by ICT. Some researcher believe that ICT can solve some problematic of language learning. Arabic Language Learning has its own problems of non-linguistic that make some difficulties to the learner. This paper discusses the role of ICT in improving the quality of learning Arabic by optimizing the use of ICT in improving cultural competence in learning.
\end{abstract}

Keywords: ICT, arabic language learning, culture

Abstark: ICT dalam pendidikan menjadi suatu hal yang sedang dibahas saat ini. Pembelajaran bahasa Arab sebagai bagian dari pembelajaran bahasa Asing merupakan salah satu aspek yang dipengaruhi oleh ICT. Beberapa peneliti percaya bahwa ICT dapat memecahkan beberapa masalah pembelajaran bahasa. Pembelajaran bahasa Arab memiliki masalah non-linguistik yang membuat beberapa pelajar mengalami kesulitan. Tulisan ini membahas peran ICT dalam meningkatkan kualitas pembelajaran bahasa Arab dengan mengoptimalkan penggunaan ICT dalam meningkatkan kompetensi budaya dalam pembelajaran.

Kata Kunci: ICT, pembelajaran bahasa Arab, kebudayaan

\section{Pendahuluan}

ICT terutama internet dalam masyarakat saat ini telah menjadi gaya hidup. Hal tersebut dikarenakan masyarakat menganggap segala urusan dan pekerjaannya akan menjadi lebih mudah dengan menggunakan ICT. Dunia pendidikan pun merespon fenomena yang terjadi pada masyarakat tersebut. Ketika masyarakat menginginkan segala hal bersifat instan dan digital, maka kemudian hadir sekolah dan bentuk lembaga pendidikan lain yang menawarkan pembelajaran berbasis ICT. Namun, Jillian Dellit menyatakan bahwa ICT tidak serta merta memberikan manfaat bagi dunia pendidikan. ${ }^{1}$ Hal serupa juga dinyatakan

\footnotetext{
${ }^{1}$ Jillian Dellit, Using ICT for Quality in Teaching- Learning Evaluation Processes, p. 56-66, http://www.ictliteracy.info/rf .pdf/UsingICTQuality.pdf, (diakses 01 Mei 2013). Daud dan Hamim menekankan bahwa that successful ICT-based lessons depend on "appropriate direction, support and guidance" from teachers. Lihat: Muneira Daud dan Nor Hasni Yanti Hamim, “Engaging Language Learners in the 21 st Century through ICT in a Singapore Secondary School”, http://www.interdisciplinary.net/wp-content/uploads/2011/06/hamimcpaper
}

oleh Steve Higgins, bahwa ICT dalam pendidikan akan memberikan perbedaan yang signifikan jika digunakan dengan tepat oleh para pengajar dan pelajar yang bersangkutan. ${ }^{2}$ Demikian juga Yong Zhao menyatakan bahwa perlu diperhatikan ICT seperti apa dan bagaimana yang akan diterapkan dalam pembelajaran?. ${ }^{3}$

Di antara pembelajaran yang dapat dibantu dan didukung oleh ICT adalah pembelajaran bahasa Arab. Terutama pembelajaran bahasa

\footnotetext{
.pdf, (diakses 01 Mei 2013).

${ }^{2}$ Steve Higgins, Does ICT improve Learning and Teaching in Schools?, www.bera.ac.uk/.../ict-pur-mb-r-f-p-laug03.pdf (diakes 01 Mei 2013). Dellit menyatakan bahwa ICT memiliki kompetensi untuk meningkatkan kualitas pada teaching, learning and evaluation through improvements in cognition, pedagogies, convergence, culture, and data. Lihat: Jillian Dellit, "Using ICT for Quality in Teaching- Learning Evaluation Processes”, p. 56-66, http://www.ictliteracy.info/rf.pdf/UsingICTQuality.pdf (diakses 01 Mei 2013).

${ }^{3}$ Yong Zhao, "Technology And Second Language Learning: Promises And Problems”, p. 15. https:/ / learnweb.harvard. edu/ccdt/_uploads/documents/use\%20of\%20technology\%20 to\%20promote\%20learning\%20autonomy.pdf (diakses $01 \mathrm{Mei}$ 2013).
} 
Arab memiliki Problematika non-Linguistik, seperti: Faktor sosio-kultural. Perbedaan sosiokultural ini menyebabkan perbedaan ungkapan, istilah dan nama benda. Salah satunya adalah perbedaan dalam memahami peribahasa. ${ }^{4}$ Selain itu, faktor lingkungan sosial yang berkaitan dengan fakta yang menyatakan bahwa berbahasa adalah terbiasa (practices makes perfect). Di antara kendalanya adalah sulitnya ditemukan bíah lughâwiyyah yang dapat memfasilitasi pelajar bahasa untuk mempraktikkan bahasa yang dipelajarinya. Namun, hal ini dapat diatasi dengan komitmen bersama untuk menciptakan bíah lughâwiyyah di lingkungan sekolah, kampus dan lainnya. Karena itu, dapat diketahui bahwa pembelajaran bahasa Arab memiliki problematika dalam pembelajarannya, terutama bagi pembelajaran bahasa Arab untuk non-Arab. Hal tersebut dikarenakan karakteristik bahasa Arab yang membedakannya dengan bahasa lainnya. Karena itu, kehadiran ICT dinilai dapat memberikan solusi dari problematika yang terdapat dalam pembelajaran bahasa Arab tersebut.

Kehadiran ICT dalam dunia pendidikan memberikan alternatif yang bervariasi. Seperti hadirnya e-learning, distance learning dan lainnya. Pemanfaatan dalam segi media pembelajaran pun makin beragam, dimulai dengan penggunaan TV, Radio di dalam kelas hingga internet. Keefektifan ICT dalam pembelajaran pun banyak diperdebatkan. Peran guru dalam pembelajaran juga menjadi pertanyaan. Di antara pembelajaran yang sering menggunakan ICT adalah pembelajaran bahasa asing. ICT memiliki peran penting dalam

\footnotetext{
${ }^{4}$ Contohnya, peribahasa Arab berbunyi يحمل التمرة إلى البصرة. (yahmilu al-tamrat ilâ al-bashrat) jika diartikan secara harfiah berarti "membawa kurma ke kota bashrah". Penerjemahan secara harfiah tidak cukup untuk memahami peribahasa ini, pemahaman sosio kultural diperlukan untuk memahami maksud peribahasa tersebut. Kota Bashrah merupakan kota yang berlimpah dan kaya akan kurma. Maka jika seseorang membawa kurma ke Bashrah tersebut, sama artinya ia melakukan hal yang sia-sia. Makna ini sama dengan makna peribasa Indonesia "membuang garam ke laut".
}

pembelajaran bahasa asing terutama untuk membantu pencapaian kompetensi kebudayaan yang sering tidak tersampaikan dalam pembelajarannya. Hal ini sesuai dengan yang dinyatakan oleh Ernest McCarus, bahwa model pembelajaran bahasa asing yang banyak dibicarakan saat ini adalah suatu model yang mengintegrasikan antara stuktur kebahasaan dengan budaya. McCarus menambahkan bahwa para pelajar bahasa asing sering ditakutkan dengan budaya dan lingkungan yang berbeda. ${ }^{5}$ Karena itu, menurutnya pembelajaran bahasa seharusnya disandingkan dengan pembelajaran budaya, agar tidak terjadi gegar budaya (culture shock). ${ }^{6}$

Ahmad Fuad Effendy menyatakan bahwa kompetensi kultural (kafầah tsaqâfiyyah) merupakan pemahaman terhadap budaya bahasa dalam berbagi segi, baik budaya Arab dan islam serta budaya-budaya universal lainnya.

R. Michael Paige dkk menyebutkan bahwa tujuan pembelajaran budaya adalah untuk mengalihkan bentuk pembelajaran yang berupa penghapalan bentuk kebudayaan kepada

\footnotetext{
${ }^{5}$ Ernest McCarus, "The Use of Proverbs in the Teaching of Arabic", Language Learning: a Jurnal of Applied Linguistics, Vol VI, Numbers 3 and 4, 30 .

${ }^{6}$ Douglas Brown mendefinisikan gegar budaya sebagai fenomena yang berentang dari ketersinggungan ringan sampai panik dan krisis psikologis yang dalam. Gegar budaya tersebut diasosiasikan dengan perasaan keterasingan, marah, bermusuhan, bimbang, frustasi, gundah, sedih, kesepian, kangen rumah dan bahkan sakit fisik. H. Douglas Brown, Principles of Language Learning and Teaching (New Jersey: Prentice Hall Regents, 1994), p.213.

${ }^{7}$ Selain kompetensi kebudayaan tersebut terdapat dua kompetensi lain yang harus dicapai oleh pelajar bahasa Arab, yaitu kompetensi kebahasaan (kafầah lughâwiyyah) yaitu mencangkup dua hal, yaitu: (1) kemahiran berbahasa yang terdiri atas kemahiran al-Istimâ', al-Kalâm, al-Qirâ'at, dan alKitâbat. (2) penguasaan unsur-unsur bahasa yang terdiri atas, alAshwât, al-Mufradât, al-Tarâkib al-Nahwiyat. dan kompetensi komunikatif (Kafâ'ah ittishâliyyah) yaitu kemampuan berkomunikasi dengan penutur asli dalam konteks sosial yang berterima, baik secara lisan maupun tulisan dan mampu mengekspresikan dirinya secara layak dalam berbagai posisi kemasyarakatan. Lihat: Ahmad Fuad Effendy, Metodologi Pengajaran Bahasa Arab (Malang: Misykat, 2009), h. 72-73.
} 
pembelajaran dengan hasil yang lebih tinggi, yaitu kemampuan untuk berinteraksi. ${ }^{8}$

Makalah ini akan menawarkan konsep penggunaan ICT yang dapat diterapkan dalam kelas pembelajaran bahasa Arab untuk tujuan peningkatan kompetensi kultural (kafäah tsaqáfiyyah). Kompetensi kultural tersebut diperlukan dan dianggap penting saat ini. Terutama dalam pendekatan komunikatif untuk dapat mendorong pelajar mampu berinteraksi dengan masyarakat pada umumnya.

\section{Kompetensi Kultural dalam Pembelajar- an Bahasa Arab}

Untuk memberikan pembelajaran budaya dalam kelas bahasa, perlu ditentukan bentuk kebudayaan seperti apa yang akan diberikan. Apakah berupa wujud kebudayaan seperti nilainilai, norma dan aturan lainnya, ataukah budaya yang merupakan bentuk aktivitas suatu masyarakat, atau budaya yang berupa benda hasil karya suatu masyarakat. Dalam suatu pengajaran bahasa, bentuk budaya yang berupa nilai, banyak dibicarakan.' Koentjaraningrat menyatakan bahwa sebuah nilai (value) adalah sebuah konsepsi, eksplisit atau implisit, yang khas milik seseorang individu atau suatu kelompok, tentang yang seharusnya diinginkan yang mempengaruhi pilihan yang tersedia dari bentuk-bentuk, caracara, dan tujuan-tujuan tindakan). Nilai sebagai suatu standar (pengukuran, penilaian) juga dapat berarti konsepsi tentang the desirable. The desirable tidak sama dengan the desired. The desirable adalah konsepsi tentang sesuatu 'yang seharusnya diinginkan', sedangkan the desired

\footnotetext{
${ }^{8}$ Paige, R. Michael dan Jorstad. Helen, "Culture Learning in Language Education: a Review of the Literature" dalam Culture as the core: perspectives on culture in second language learning ed. Dale L. Lange dan R. Michael Paige (New York: Information Age Publishing, 2003), p.175.

${ }^{9}$ David Graeber, Toward an Anthropological Theory of Value (New York: Palgrave, 2001), p. 10. Lihat juga Amri Marzali, Pergeseran Orientasi Nilai Kultural dan Keagamaan di Indonesia dalam Jurnal Antropologi Indonesia Vol. XXII, No. 57, September-Desember 1998.
}

adalah hal 'yang diinginkan'. Nilai merupakan kriteria dalam menentukan tentang apa yang seharusnya diinginkan seseorang sebagai anggota suatu masyarakat, bukan tentang apa yang diinginkannya. ${ }^{10}$

Selain itu, H.D. Hidayat menyatakan bahwa pembelajaran bahasa Arab tidak dapat dipisahkan dari kebudayaan Islam. Karena kedatangan Islam memberikan pengaruh terhadap kebudayaan serta bahasa Arab. Islam dan bahasa Arab memiliki hubungan timbal balik yang saling menguatkan. Bahasa Arab memiliki keistimewaan yang mampu menyalurkan nilainilai keislaman, begitu juga Islam dengan alQur'an menjadi peran penting dalam mengokohkan kedudukan bahasa Arab. ${ }^{11}$

Fathi Yûnus menyatakan bahwa metode pembelajaran budaya bagi pelajar non-Arab terdiri dari dua metode, yaitu: pertama, memberikan waktu khusus untuk pembelajaran budaya. Kedua, tidak memberikan waktu khusus untuk pembelajaran budaya. ${ }^{12}$ Yûnus juga menambahkan bahwa materi kebudayaan yang dapat mendukung kemahiran berbahasa pelajar bahasa Arab, antara lain: peninggalan peradaban, identitas pribadi, hubungan tempat dan waktu, hubungan dengan orang lain, layanan publik, perjalanan, di restoran, di pasar, mata uang, nama-nama, penomoran, tempat tinggal, kesehatan, cuaca, tempat-tempat penting, acaraacara hari besar, pekerjaan, pendidikan dan pengajaran, waktu luang, bahasa asing, agama dan nilai-nilai spritirual, politik dan hubungan internasional, dan ekonomi. ${ }^{13}$ Materi tersebut dapat disampaikan pada saat pembelajaraan kemahiran berbahasa, seperti dalam

10 Koentjaraningrat, Pengantar Ilmu Antropologi (Jakarta: Rineka Cipta, 1990), h.186.

${ }^{11}$ D. Hidayat, Tadrîs al-Lughah al- 'Arabiyyah 'ala Dhau'i alMadkhal al-Lughawî al-Ijtimâî̀, http: / / www.atida.org/melayu /index.php?option=com_cont, $($ diakses 07 Mei 2013).

${ }^{12}$ Fathi 'Ali Yûnus dan Muhammad 'Abd al-Rauf, al-Marja' fî Ta 'îm al-Lughah al- 'Arabiyyah li al- 'Ajânib; min al-Nazhariyyah ila al-Tathbîq (Kairo: Maktabah Wahabiyyah, 2003), h.135.

${ }^{13}$ Fathi 'Ali Yûnus dan Muhammad 'Abd al-Rauf, al-Marja', h. $137-145$. 
pembelajaran muhâdatsah, Qawâ‘id, Nushûsh adabiyyah dan lainnya, pemberian pemahaman kebudayaan diberikan dengan menyampaikan contoh-contoh dari ayat-ayat al-Qur'an, hadits ataupun dari peribahasa. ${ }^{14}$

Pembelajaran budaya dalam kelas bahasa memiliki beberapa model. Plastina membagi model pembelajaran budaya tesebut, menjadi: Pertama, the language enjoyment model, yaitu model yang mengajarkan budaya dengan membahasnya dalam makna istilah kosakata baru yang akan diajarkan. Kedua, the language skill model, yaitu model yang mensyaratkan penggunaan bahasa dan budaya dapat dipisahkan, setidaknya untuk tujuan pembelajaran. Ketiga, survival model, model yang menyampaikan informasi kebudayaan lebih banyak. Model ini mengasumsikan bahwa sistem bahasa dan budaya tidak dapat dipisahkan. Keempat, academic model yaitu suatu model pengajaran yang berorientasi pada pengujian. Hal ini disebabkan karena dorongan pemenuhan kompetensi kebahasaan, maka pembelajaran difokuskan pada aspek kebahasaan saja. ${ }^{15}$

Pembelajaran budaya dalam kelas bahasa dapat dilakukan dengan berbagai cara. Pertama cara yang dikemukakan oleh Peterson dan Coltrane. Menurutnya pembelajaran budaya dalam kelas dapat dilakukan dengan cara menggunakan bahan yang autentik yang didapat dari masyarakat penutur asli. Bahan tersebut dapat berupa film, siaran berita, televisi, website, majalah, menu restauran, brosur travel dan lainnya. Selain itu, pembelajaran budaya juga dapat menggunakan peribahasa dan juga dapat menggunakan cara bermain peran (role play), memberikan tugas kepada pelajar untuk menghadirkan objek yang merupakan simbol dari kebudayaan masyarakat tersebut,

\footnotetext{
${ }^{14}$ Fathi 'Ali Yûnus dan Muhammad 'Abd al-Rauf, al-Marja', h. 235 .

${ }^{15}$ Anna Franca Plastina, ESL Culture in The Classroom, (Italia: Universitá Della Calabria), p. 20. http://www.educ.utas.edu .au (diakses pada 02 Juni 2013).
}

menghadirkan pertukaran pelajar dan studi etnografi. $^{16}$ Berdasarkan pendapat yang dikemukakan oleh Peterson dan Coltrane tersebut, penulis mengasumsikan bahwa ICT dapat menjadi gerbang untuk pembelajaran budaya dalam kelas bahasa. Dengan beberapa fasilitas dan kemudahan yang dapat didapatkan melalui ICT, seperti $\epsilon$-culture dan lain sebagainya.

\section{Aspek Pembelajaran Bahasa dengan ICT}

Young Zhao menyatakan bahwa ICT memiliki potensi besar dalam peningkatan kualitas pembelajaran bahasa asing. Namun, Zhao menyatakan bahwa potensi ICT tersebut harus diimbangi dengan potensi pengajar untuk mampu memilih dan menetapkan ICT bentuk apa yang akan diterapkan dalam proses pembelajaran bahasa. Hal tersebut dikarenakan, bentuk satu teknologi yang sama dapat memiliki fungsi dan kegunaan yang berbeda. Lebih lanjut lagi Zhao menyatakan bahwa manfaat teknologi hanya dapat dirasakan dengan penggunaan yang tepat. $^{17}$

Menurut Daud dan Hamim beberapa kesalahan cara pandang terhadap penggunaan ICT dalam pembelajaran bahasa, di antaranya: Pertama, kita sering terfokus pada penggunaan satu teknologi saja, tanpa memandangnya secara komprehensif terhadap beberapa teknologi. Seperti, kita sering disibukkan dengan satu program software pembelajaran, tanpa memikirkan bahwa software tersebut memerlukan perangkat komputer untuk membacanya. Sedangkan masih ada di antara pelajar yang tidak memiliki komputer di rumahnya. Kedua, konsep tradisional terhadap penggunaan ICT dalam pembelajaran bahasa

\footnotetext{
${ }^{16}$ Elizabeth Peterson dan Bromwym Coltrane, Culture in Second Language Teaching, Eric Digest, Desember 2003, http://www.cal.org/resources/digest/digest_pdfs/0309peter son.pdf (diakses pada 04 Juni 2013).

${ }_{17}$ Yong Zhao, Technology And Second Language Learning: Promises And Problems, p. 26. (diakses 01 Mei 2013).
} 
adalah bahwa ICT digunakan hanya untuk meningkatkan salah satu kemahiran berbahasa, tanpa memandang untuk meningkatkan proses pembelajaran bahasa secara menyeluruh. Sebagai contoh, suatu laman pembelajaran bahasa Arab http://pba.aldakwah.org/ yang hanya menyediakan pembelajaran percakapan dan tata bahasa. Ketiga, penggunaan teknologi dalam pembelajaran bahasa cenderung berfokus pada teknologi terbaru dan melupakan teknologi lama. Keempat, penelitian tentang ICT dalam pembelajaran bahasa cenderung berfokus pada pembelajaran untuk dewasa (adult learning). ${ }^{18}$

Zhao mengemukakan empat aspek yang harus diperhatikan dalam penerapan ICT dalam pembelajaran bahasa asing, yaitu: Pertama, teknologi yang dapat meningkatkan kualitas input bahasa pelajar. Kedua, teknologi yang dapat mengembangkan bentuk latihan berbahasa serta memberikan umpan balik (feedback) yang tepat. Ketiga, teknologi yang mampu memfasilitasi kemudahan komunikasi. Keempat, komunikasi yang dapat menopang motivasi pelajar. ${ }^{19}$ Dengan demikian, pembelajaran bahasa yang efektif dengan menggunakan ICT hanya dapat tercapai jika ke empat aspek terpenuhi, yaitu: (1) input bahasa, (2) kesempatan praktik untuk komunikasi, (3) feedback, dan (4) motivasi individu pelajar.

\section{High Quality Input, Proses dan Feedback dalam Pembelajaran Bahasa dengan ICT}

Zhao menyatakan bahwa kesuksesaan pembelajaran bahasa kedua atau bahasa apapun,

${ }^{18}$ Daud dan Hamim menyatakan bahwa saat ini para pengajar tidak lagi dapat memisahkan apakah hanya akan mengajar, atau hanya mempelajari kembali teknologi secara terpisah. Daud menambahkan bahwa Teachers have to be able to integrate the two and "adapt their practice or adopt new approaches in order to maximize the potential of the new technologies" to become successful facilitators of learning. Lihat: Muneira Daud dan Nor Hasni Yanti Hamim, Engaging Language Learners in the 21st Century through ICT in a Singapore Secondary School, http://www.inter-disciplinary.net/wp (diakses 01 Mei 2013).

${ }_{19}$ Yong Zhao, Technology And Second Language Learning: Promises And Problem, p. 22-26 hanya dapat terlaksana dengan baik jika diimbangi dengan input kebahasaan dan budaya bahasa target yang cukup, beragam dan otentik.

Mengenai input kebahasaan dan budaya dalam pembelajaran bahasa, ICT memberikan beragam macam, seperti: TV, khususnya TV satelit, video dan audio recorders/players, bahkan film merupakan media yang efektif untuk memperkenalkan bahasa dan budaya yang autentik bagi pelajar bahasa. TV, Radio dan film tersebut banyak digunakan dalam pembelajaran. ${ }^{20}$

Program Arabic for Non-Native Speakers yang berada di Universitas Qatar adalah salah satu contoh program pembelajaran bahasa Arab yang telah banyak menggunakan ICT untuk mendukung input kebahasaan dan budaya Arab bagi para pelajarnya. Di antara program yang banyak digunakan adalah media TV dan atau live streaming dari acara TV al-jazeera. Bahkan potongan-potongan berita al-Jazeera yang telah diunggah dalam youtube juga digunakan dalam proses belajarnya. Sedangkan pada program Jurusan bahasa dan Sastra Arab di Universitas Negeri Jakarta, input kebahasaan dan budaya yang menggunakan ICT digunakan dalam mata kuliah istimâ'. Dalam proses pembelajarannya digunakan CD pembelajaran al-'Arabiyyah bayna yadaik, bahkan sesekali diputarkan film kartun ataupun sinetron Arab.

Dengan demikian, ICT memiliki peran penting dalam menopang input kebahasaan dan budaya dalam pembelajaran bahasa Arab. Zhao menjabarkan bahwa ICT dapat digunakan untuk meningkatkan kualitas input bahasa melalui beberapa cara, yaitu: Pertama, meningkatkan efisiensi akses melalui teknologi multimedia digital. Kedua, meningkatkan keautentikan bahasa dan budaya dengan menggunakan video atau internet. Ketiga, meningkatkan

\footnotetext{
${ }^{20}$ Yong Zhao, Technology And Second Language Learning: Promises And Problem, p. 25
} 
kesinambungan antara pemahaman pelajar dan multimedia. $^{21}$

Selain itu, penggunaan ICT juga dapat dilakukan untuk memberikan peluang praktik komunikasi yang lebih mudah bagi pelajar bahasa asing. Seperti kita ketahui, dengan jaringan internet dan sosial media yang semakin mudah diakses dapat memberikan kemudahan berkomunikasi bagi para pelajar. Pelajar dapat dengan mudah mendapatkan komunitaskomunitas yang dapat membantu dalam peningkatan kemahiran berkomunikasinya. Suatu riset yang dilakukan oleh Meei Ling Liaw yang menyatakan bahwa dengan menggunakan e-forum, para pelajar mampu meningkatkan kompetensi kebudayaan (intercultural competence). Selain itu, para pelajar juga mampu berkomunikasi dengan lancar tanpa alat bantu seperti e-dictionary dan lainnya. Selain itu, Zhao juga memberikan alternatf penggunaan ICT untuk kepentingan komunikasi para pelajar, seperti sistem yang disebutnya dengan computer Mediated Communication (CMC). CMC merupakan teknologi yang memungkinkan pelajar untuk berinteraksi sosial dengan rekanrekannya, baik antar sesama non-native speakers, ataupun dengan native speakers. Di antara bentuk CMC adalah email, discussion board, online chat, dan audio/video conferencing. Maka, dengan demikian dapat diciptakan proses pembelajaran bahasa yang baik dengan memiliki peluang praktik berkomunikasi dengan lebih maksimal.

Selajutnya, ICT mampu memberikan feedback yang berkualitas bagi para pelajar bahasa. Seperti dalam pembelajaran bahasa Inggris, kita kenal software seperti talkthome yang memberikan feedback dalam pronounciation. Zhao menyatakan bahwa

\footnotetext{
${ }^{21}$ Yong Zhao, Technology And Second Language Learning: Promises And Problems, p. 24.

${ }^{22}$ Meei-ling Liaw, E-Learning And The Development Of Intercultural Competence, Language Learning \& Technology, September 2006, Volume 10, Number 3, 49-64, http://llt.msu.edu/vol10num3/liaw/ (diakses 01 Mei 2013).
}

feedback dalam pronounciation terkadang menemukan kendala, terutama jika feedback hanya mengandalkan dari pengajar. Karena pengajar terkadang juga menemukan kesulitan dalam memberikan penilaian dalam pengucapan. Terutama dalam pembalajaran bahasa Arab yang memiliki karakteristik khusus dalam pengucapannya. ${ }^{23}$ Selain itu, feedback tersebut juga dengan mudah kita temukan dalam spell dan grammar checkers di program Microsoft office. Jacobs dan Rodgers, seperti dikutip Zhao, menyatakan bahwa Computer-based grammar checkers dan spell checkers merupakan cara yang potensial untuk mendukung kemahiran menulis para pelajar.

\section{ICT dan Motivasi Pelajar Bahasa}

Zhao menyatakan bahwa perbedaan individu pelajar dapat mempengaruhi performance dan motivasi pelajar. Zhao mengingatkan bahwa tidak semua pelajar memiliki bakat berbahasa (linguistic aptitude) yang sama. Selain itu, setiap pelajar juga memiliki kecenderungan dan tujuan yang berbeda dalam mempelajari berbahasa. Maka, Zhao menyatakan bahwa tidak bijak jika memaksakaan tiap individu pelajar untuk dapat menguasai secara rata keempat kemahiran

\footnotetext{
${ }^{23}$ Ada beberapa fonem yang harus diperhatikan oleh pelajar bahasa Arab nonArab, khususnya para pelajar Indonesia. Beberapa fonem yang tidak ada padanannya dalam fonem

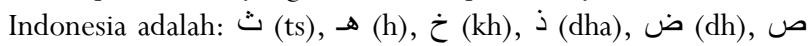
(sh), ط (th), ظ (zh), ع ('a), غ (gh). Menanggapi perbedaan fonem tersebut, Ahmad Izzan menyatakan bahwa pelajar Indonesia memiliki banyak kesempatan untuk mempelajari fonem tersebut dari kesempatan mendengarkan dan mengucapkan huruf-huruf tersebut saat membaca al Qur'an, mendengar azan, iqamah, dan lainnya. Izzan menambahkan bahwa dalam pembelajaran bahasa Arab tidak sama dengan pengajaran membaca al Qur'an, dalam pembelajaran bahasa Arab tidak harus diberlakukan penggunaan hukum bacaan, seperti ikhfa, idhgam, izhar, dan hukum nun mati atau tanwin. Lihat: Ahmad Izzan, Metodologi Pembelajaran Bahasa Arab (Bandung: Humaniora, 2009), Ct 3, 68.
} 
berbahasa, seperti berbicara, menulis, membaca dan mendengar. ${ }^{24}$

Selanjutnya, Zhao menyatakan bahwa pelajar memiliki stategi dan model belajar yang berbeda. Mengutip Pennington, Zhao menyarankan sistem pengajaran yang ideal, yang dapat diterapkan dalam proses pembelajaran bahasa, yaitu:

(1) Helps learners develop and elaborate their increasingly specified cognitive representation for the second language;

(2) Allows learners to experiment and take risks in a psychologically favorable and motivating environment;

(3) Offers input to both conscious and unconscious learning processes;

(4) Offers learners opportunities to practice and to receive feedback on performance;

(5) Allows learners to learn according to their own purposes and goals;

(6) Puts learners in touch with other learners;

(7) Promotes cultural and social learning;

(8) Promotes interactivity in learning and communication;

(9) Exposes the learner to appropriate contexts for learning;

(10) Expands the learner's 'zone of proximal development';

(11) Builds to learner independence. ${ }^{25}$

Selain itu, Muneira Daud dan Nor Hasni Yanti Hamim melakukan penelitian mengenai motivasi pelajar dalam pembelajaran di kelas dengan menggunakan ICT. Hasilnya 80\% pelajar menyatakan lebih menyukai pembelajaran yang menggunakan ICT. Hal tersebut terlihat dari tabel berikut:

\footnotetext{
${ }^{24}$ Yong Zhao, Technology And Second Language Learning: Promises And Problem, p. 10-11.

${ }^{25}$ Yong Zhao, Technology And Second Language Learning: Promises And Problem, p. 9.
}

\begin{tabular}{|c|c|c|c|c|}
\hline & $\begin{array}{c}\text { Strongly } \\
\text { Agree }\end{array}$ & Agree & Disagree & $\begin{array}{l}\text { Strongly } \\
\text { Disagree }\end{array}$ \\
\hline $\begin{array}{l}\text { I feel when my teacher } \\
\text { uses Web } 2.0 \\
\text { technologies in class. }\end{array}$ & $\begin{array}{c}211 \\
(25.42 \\
\%)\end{array}$ & $\begin{array}{c}492 \\
(59.28 \\
\%)\end{array}$ & $\begin{array}{l}95 \\
(11.45 \\
\%)\end{array}$ & $\begin{array}{c}32 \\
(3.86 \\
\%)\end{array}$ \\
\hline $\begin{array}{l}\text { I feel motivated my } \\
\text { teacher uses Web } 2.0 \\
\text { technologies in class. }\end{array}$ & $\begin{array}{c}198 \\
(23.86 \\
\%)\end{array}$ & $\begin{array}{l}459 \\
(55.30 \\
\%)\end{array}$ & $\begin{array}{c}132 \\
(15.90 \\
\%)\end{array}$ & $\begin{array}{c}41 \\
(4.94 \\
\%)\end{array}$ \\
\hline $\begin{array}{lr}\text { I enjoy learning } & \text { using } \\
\text { ICT/Web } & 2.0 \\
\text { tecnologies } & \text { during } \\
\text { lessons. } & \end{array}$ & $\begin{array}{l}221 \\
(26.63 \\
\%)\end{array}$ & $\begin{array}{c}496 \\
(59.76 \\
\%)\end{array}$ & $\begin{array}{c}81 \\
(9.76 \\
\%)\end{array}$ & $\begin{array}{c}31 \\
(3.73 \\
\%)\end{array}$ \\
\hline $\begin{array}{lr}\text { ICT/Web } & 2.0 \\
\text { technologies } & \text { have } \\
\text { aroused my interest in } \\
\text { learning. }\end{array}$ & $\begin{array}{c}196 \\
(23.61 \\
\%)\end{array}$ & $\begin{array}{c}462 \\
(55.66 \\
\%)\end{array}$ & $\begin{array}{c}134 \\
(16.14 \\
\%)\end{array}$ & $\begin{array}{l}38 \\
(4.56 \\
\%)\end{array}$ \\
\hline $\begin{array}{l}\text { ICT/Web } 2.0 \\
\text { technologies enable me } \\
\text { to learn better as } \\
\text { compared to the normal } \\
\text { teaching methods. }\end{array}$ & $\begin{array}{c}183 \\
(22.05 \\
\%)\end{array}$ & $\begin{array}{c}445 \\
(53.61 \\
\%)\end{array}$ & $\begin{array}{l}155 \\
(18.67 \\
\%)\end{array}$ & $\begin{array}{l}47 \\
(5.66 \\
\%)\end{array}$ \\
\hline
\end{tabular}

Berdasarkan penelitian tersebut, dapat dinyatakan bahwa ICT memiliki peran dalam meningkatkan motivasi pelajar. Maka, penulis menyarankan untuk menggunakan ICT dalam pembelajaran bahasa di kelas. Karena ICT selain dapat memudahkan pengajar dalam menyampaikan materi, ICT juga telah menjadi sesuatu yang akrab dalam keseharian pelajar. Dengan demikian, ICT juga dapat membantu pelajar dalam memahami materi serta menumbuhkan motivasinya.

\section{Peran ICT dalam Meningkatkan Pemaha- man antarbudaya}

Meei Ling Liaw menyatakan bahwa dalam pembelajaran budaya dalam kelas bahasa, perlu didefinisikan budaya seperti apa yang akan diajarkan. $^{26}$ Bertelsmann Stiftung dan Fondazione Cariplo menyatakan bahwa budaya seperti layaknya bawang yang memiliki lapisan luar dan juga memiliki lapisan dalam terdapat yang tiap lapis tersebut terdiri dari beraneka bentuk. Lebih lanjutnya, sebagai berikut:

\footnotetext{
26 Meei-ling Liaw, E-Learning And The Development Of Intercultural Competence, p. 15.
} 
Like an onion culture may include an outer layer of what people primarily associate with culture: the visible reality of behavior, clothes, food, language, housing, etc. (explicit culture) as well as hidden layers containing the norms and values a society holds (normative layer) and deeper layers of basic assumptions and world views (implicit culture). ${ }^{27}$

Dalam cara yang biasanya terjadi dalam pembelajaran budaya adalah dengan menggunakan pendekatan cross cultural constrastive (cross cultural contrastive approach). Dengan pendekatan ini, para pelajar diminta untuk dapat membandingkan budaya target dengan budayanya sendiri. Liaw menyatakan bahwa pemahaman budaya dalam pembelajaran bahasa asing mulai dirasakan pentingnya saat lahirnya pendekatan komunikatif dalam pembelajaran bahasa. Kemudian dikenal dengan sebutan intercultural competence. Straub menyatakan, seperti yang dikutip oleh Liaw, bahwa:

Learners must first become familiar with what it means to be part of their own culture and by exploring their own culture (by discussing the values, expectations, traditions, customs, and rituals they unconsciously take part in) before they are ready to reflect upon the values, expectations, and traditions of others with a higher degree of intellectual objectivity. ${ }^{28}$

Dengan demikian, para pengajar juga harus memastikan bahwa pelajar bahasa asing telah mengenal dengan baik budayanya sendiri. Hal tersebut tentunya dibutuhkan agar para pelajar tidak kehilangan jati diri bangsanya. Abrams, seperti yang dikutip Liaw, menyatakan bahwa: Foreign language teachers should help learners reorganize their own complex cultural microcosmos and offer learners opportunities to

\footnotetext{
${ }^{27}$ Bertelsmann Stiftung \& Fondazione Cariplo, Intercultural Competence - The key competence in the 21st century, 5, http://www.bertelsmann-stiftung.de/bst/de/media/xcms _bst_dms_30238_30239_2.pdf (diakses 01 Mei 2013).

${ }_{28}$ Meei-ling Liaw, E-Learning And The Development Of Intercultural Competence, p. 28.
}

develop skills to investigate cultural complexity and to promote cultural curiosity. ${ }^{29}$

Bertelsmann Stiftung dan Fondazione Cariplo memberikan gambaran tentang pemahaman intercultural sebagai berikut:

Intercultural competence is the ability to interact effectively and appropriately in intercultural situations; it is supported by specific attitudes and affective features, (inter)cultural knowledge, skills and reflection. ${ }^{30}$

Kemudian, berdasarkan definisi tersebut, Stiftung dan Cariplo menjabarkan proses intercultural yang terdiri dari empat dimensi, yaitu: ${ }^{31}$

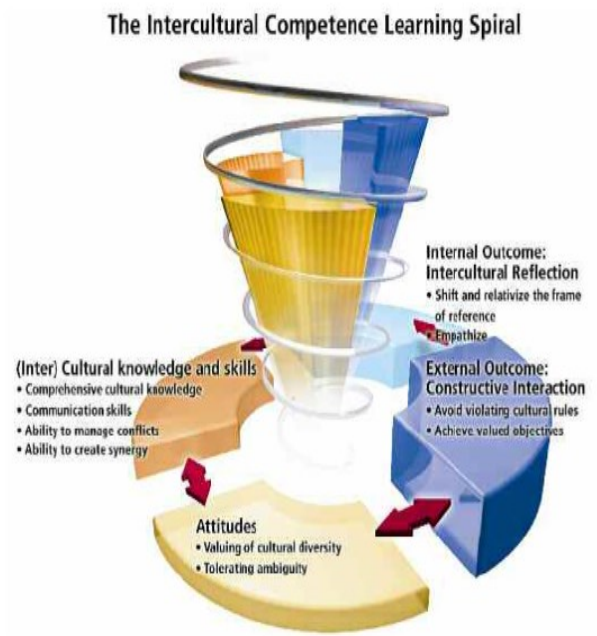

Selanjutnya, beberapa cara dapat dilakukan untuk mendukung pembelajaran budaya dalam kelas bahasa dengan menggunakan ICT, seperti: e-forum. Liaw menyatakan bahwa melalui e-forum, para pelajar mampu mencapai keempat kompetensi intercultural, yaitu:

(a) interest in knowing other people's way of life and introducing one's own culture to others, (b) ability to change perspective, knowledge about one's own and others' culture for intercultural communication, and (d)

\footnotetext{
29 Meei-ling Liaw, E-Learning And The Development Of Intercultural Competence, p. 22.

${ }^{30}$ Bertelsmann Stiftung \& Fondazione Cariplo, Intercultural Competence, p. 15.

${ }^{31}$ Bertelsmann Stiftung \& Fondazione Cariplo, Intercultural Competence, p. 20.
} 
knowledge about intercultural communication processes. $^{32}$

Selain itu, Kristina Mullamaa juga menyatakan bahwa e-learning merupakan pilihan yang tepat untuk pembelajaran bahasa. Mullamaa menegaskan bahwa pengalamannya dalam menerapkan aplikasi Blackboard $\epsilon$ learning. Terbukti bahwa penggunaan aplikasi tersebut meningkatkan kualitas belajar pengajaran bahasa Inggris dan Swedia di tempatnya. ${ }^{33}$ Begitu juga dengan Minjie Xing, Jinghui Wang, dan Kenneth Spencer menyatakan bahwa dengan pembelajaran dengan menggunakan e-learning melalui e-group mampu meningkatkan pemahaman antarbudaya. $^{34}$

Dengan demikian, dapat disimpulkan bahwa ICT memiliki peran yang penting dalam meningkatkan pemahaman antarbudaya pelajar bahasa. Beberapa contoh media berbasis ICT yang dapat diterapkan dalam pembelajaran bahasa Arab, seperti yang ditulis oleh Taufik Siraj dalam blognya. ${ }^{35}$

\section{Penutup}

Program pembelajaran bahasa yang efektif hendaknya memberikan pembekalan bahasa yang dapat digunakan dalam dan luar kelas. Kita tidak dapat mengharapkan bahwa ICT dengan sendirinya mampu menciptakan proses pembelajaran yang efektif. Kita harus menyadari bahwa pengajar dan keluarga, juga harus bekerja

32 Meei-ling Liaw, E-Learning And The Development of Intercultural Competence, p. 24.

${ }^{33}$ Kristina Mullamaa, ICT in Language Learning - Benefits and Methodological Implications, International Education Studies, Vol. 3, No.1, Februari 2010, p.38-44.

${ }^{34}$ Minjie Xing, Jinghui Wang, dan Kenneth Spencer, Raising Students' Awareness Of Cross-Cultural Contrastive Rhetoric In English Writing Via An E-Learning Course, Language Learning \& Technology, Volume 12, Number 2, http://llt.msu.edu/vol12num2/xingetal/ June 2008 (diakses 02 Mei 2013).

35 Taufik Siraj, Inovasi Pembelajaran Bahasa Arab Dengan Internet, http://blog.sunan-ampel.ac.id/taufik/. p.472. (diakses 26-11-2012). sama dalam penggunaan ICT guna terwujudnya pembelajaran bahasa yang efektif di sekolah dan di rumah.

ICT hadir dalam pembelajar bukan untuk mengambil alih peran pengajar. ICT hanya dapat digunakan dengan maksimal jika didukung oleh pengetahuan dan kreativitas pengajar yang bersangkutan. Seperti dengan hadirnya internet yang memberikan beragam informasi dan kemudahan dalam materi ajar, hal tersebut perlu didukung oleh kemampuan pengajar untuk mengolahnya.

Kemudahan akses terhadap bermacam materi ajar tersebut, dan banyaknya jumlah media yang dapat dimudahkan, diharapkan dapat meningkatkan kualitas pembelajaran bahasa asing di Indonesia, terutama dalam pembelajaran bahasa Arab. Penelitian-penelitian menyatakan bahwa pembelajaran bahasa Arab di Indonesia masih bersifat pada pencapaian tata bahasa saja. Hal tersebut tidak dapat dipungkiri, karena pembelajaran bahasa Arab di Indonesia masih cenderung merujuk pada kitab kuning yang berorientasi pada pemahaman agama saja. Dengan adanya ICT diharapkan dapat memudahkan pembelajaran bahasa Arab dengan pendekatan komunikatif. Sehingga dengan demikian, dapat mendukung kompetensi bahasa serta budaya pelajar.

\section{Daftar Pustaka}

Brown H., Douglas, Principles of Language Learning and Teaching. New Jersey: Prentice Hall Regents, 1994.

Daud, Muneira \& Nor Hasni Yanti Hamim, Engaging Language Learners in the 21st Century through ICT in a Singapore Secondary School, http://www.interdisciplinary.net/wp (diakses $01 \mathrm{Mei}$ 2013).

Dellit, Jillian, Using ICT for Quality in Teaching- Learning Evaluation Processes, 56-66, http://www.ictliteracy.info/rf.pdf/Using ICTQuality.pdf (diakses 01 Mei 2013). 
Effendy, Ahmad Fuad, Metodologi Pengajaran Bahasa Arab. Malang: Misykat, 2009.

Graeber, David, Toward an Anthropological Theory of Value. New York: Palgrave, 2001.

Hidayat, HD., Tadrís al-Lughah al-'Arabiyyah 'ala Dhau'i al-Madkhal al-Lughawî alIjtimâ'ı, http://www.atida.org/ (diakses 07 Mei 2013).

Higgins, Steve, Does ICT improve Learning and Teaching in Schools: www.bera.ac.uk/.../ict-put-mb-t-t-plaug03.pdf (diakes 01 Mei 2013).

Izzan, Ahmad, Metodologi Pembelajaran Bahasa Arab. Bandung: Humaniora, 2009.

Koentjaraningrat, Pengantar Ilmu Antropologi. Jakarta: Rineka Cipta, 1990.

Liaw, Meei-ling, E-Learning And The Development Of Intercultural Competence, Language Learning \& Technology, September 2006, Volume 10, Number 3, 49-64, http://llt.msu.edu/vol10num3/liaw/ (diakses 01 Mei 2013).

Marzali, Amri Pergeseran, "Orientasi Nilai Kultural dan Keagamaan di Indonesia" dalam Jurnal Antropologi Indonesia Vol. XXII, No. 57, September Desember 1998.

McCarus, Ernest. The Use of Proverbs in the Teaching of Arabic Language Learning: a Jurnal of Applied Linguistics, Vol VI, Numbers 3 and 4, 30.

Michael, Paige, R. \& Jorstad. Helen, Culture Learning in Language Education: a Review of the Literature, Culture as the core: perspectives on culture in second language learning ed. Dale L. Lange dan R. Michael Paige. New York: Information Age Publishing, 2003.

Mullamaa, Kristina, ICT in Language Learning Benefits and Methodological Implications. International Education Studies, Vol. 3, No.1, Februari 2010, 38-44.
Peterson, Elizabeth \& Bromwym Coltrane, Culture in Second Language Teaching, Eric Digest, Desember 2003, http://www.cal.org/ (diakses pada 04 Juni 2013).

Plastina, Anna Franca, ESL Culture in The Classroom, (Italia: Universitá Della Calabria), http://www.educ.utas.edu.au/users/tle/J OURNAL/ (diakses pada 02 Juni 2013).

Siraj, Taufik, Inovasi Pembelajaran Bahasa Arab Dengan Internet, http://blog.sunanampel.ac.id/taufik/?p=472 (diakses 2611-2012).

Stiftung, Bertelsmann \& Fondazione Cariplo. Intercultural Competence - The key competence in the 21st century, 5 . http://www.bertelsmann-stiftung.de/ (diakses 01 Mei 2013).

Xing, Minjie, Jinghui Wang, \& Kenneth Spencer, Raising Students' Awareness Of Cross-Cultural Contrastive Rhetoric In English Writing Via An E-Learning Course. Language Learning \& Technology, Volume 12, Number 2,7193,

http://llt.msu.edu/vol12num2/xingetal/ June 2008 (diakses 02 Mei 2013).

Yûtnus, Fathi 'Ali \& Muhammad 'Abd al-Rauf, al-Marja' tî Ta'lim al-Lughah al'Arabiyyah li al-'Ajânib; min alNazhariyyah ila al-Tathbíq. Kairo: Maktabah Wahabiyyah, 2000.

Zhao, Yong, Technology And Second Language Learning: Promises And Problems, https://learnweb.harvard.edu/ccdt/_upl oads/documents/use $\% 20$ of $\% 20$ technol ogy $\% 20$ to $\% 20$ promote $\% 20$ learning $\% 2$ 0autonomy.pdf (diakses 01 Mei 2013). 